\title{
Implementation of the Independent Learning Curriculum in Schools Through a Synergistic Partnership Model
}

\author{
$1^{\text {st }}$ Muhammad Amin ${ }^{1}, 2^{\text {nd }}$ Muhammad Isnaini $^{2}, 3^{\text {rd }}$ Joni Syafrin Rambey $^{3}$ \\ $\left\{\right.$ aminunimed.unimed.ac.id ${ }^{1}$, misnain@unimed.ac.id ${ }^{2}$, jonisyafrinrambey@yahoo.co.id $\left.{ }^{3}\right\}$ \\ Department of Electrical Engineering Education, Universitas Negeri Medan, Medan \\ Indonesia ${ }^{1,2,3}$
}

\begin{abstract}
The implementation of lecturing activities outside the campus is very possible for students to do, including activities as a teacher assistant at school. To support the implementation of these activities, it is very necessary to have a comprehensive and relevant formulation of activities to be carried out by students in achieving lecture goals. This research is directed to: (1) find and formulate relevant activities in the form of a partnership model between study programs at universities and schools where students carry out activities, (2) activity formulations are directed to provide optimal benefits for each component of partnership activity actors. This study uses a Research and Development approach, which consists of five stages, namely (1) search, (2) analysis, (3) build, (4) revision, and (5) implementation. The partnership model developed will involve principals, teachers, students, heads of university study programs, lecturers, and students as model users. The development process also involves experts as validators in producing products supporting the partnership model. The results of the study found (1) the formulation of activities for implementing the independent learning curriculum in partner schools that were packaged in the components of the partnership model, (2) partnership activities had a positive impact on the actors of the partnership model based on their respective roles, (3) the partnership model and product tools supporters who were found to be very feasible to be applied in supporting the implementation of learning in schools. The results of this study are expected to be followed up, and expanded based on the needs of the institution, so that there is a synergy between educational institutions and education personnel with schools as one of the users of graduates.
\end{abstract}

Keywords: Partnership model, teacher assistance in schools, synergistic educational institutions.

\section{Introduction}

Various observations and analyzes (Depdiknas, 2002), found at least three factors that caused the quality of education in Indonesia to be uneven, namely; 1) National education implementation policies that use an education production function or input-output analysis approach; 2) National education is held in a centralized bureaucratic manner, and 3) School stakeholder involvement in education is still minimal. The education production function or input-output analysis approach views that the school functions as a production center which if the input requirements are met in the production process, the school will produce the desired output. This approach assumes that if educational inputs such as teachers, textbooks, learning 
media, educational facilities are met, then the quality of education will automatically be achieved. In reality, when this has been attempted, it does not necessarily increase the quality of education. Why did this happen? because the education production function approach focuses too much on educational input and pays less attention to the educational process, even though the education process is very influential on educational output; National education is also carried out in a centralized bureaucratic manner, so that the existence of schools is very dependent on very complicated bureaucratic decisions and sometimes bureaucratic decisions are not in accordance with local school conditions. Schools are subordinated to the bureaucracy above it, so schools do not have the independence, flexibility, and initiative to advance their institutions.

The involvement of school stakeholders in the implementation of education, especially teachers, other educational institutions, the business world and industry, and related social institutions is considered to be very minimal. Teacher participation in decision making is often ignored, even though teachers are the spearhead in creating school change for the better. Whatever reform efforts the school seeks, if it does not get full support from the teacher, the renewal will never materialize. Meanwhile, the participation of parents and the community so far has generally only been limited to financial support, while other supports such as moral thinking, management, services have received less attention. School accountability to the community is also weak. Schools do not seem to have the burden to account for the results of the implementation of education to the community, especially parents of students as the main stakeholders in education.

Based on these conditions, an institution or organization, especially an educational institution, in carrying out its activities must always try to develop a unified cooperation (partnership), by utilizing existing resources in order to achieve the previously set common goals. One strategy that can be done is to hold a collaboration. Cooperation or partnership itself has several etymological meanings, partnership is adapted from the word Partnership, and comes from the root word partner. Partner can be translated "partner, soul mate, ally or companion". While partnership is translated into partnership or partnership. [1] Meanwhile, according to Soekidjo Notoatmojo [2], Partnership is a formal cooperation between individuals, groups, or organizations to achieve a certain task or goal. In this cooperation there is an agreement about the commitments and expectations of each, about the review of the agreements that have been made, and sharing both the risks and the benefits that have been obtained. According to Sentanoe Kertonegoro [3] partnership is a beneficial cooperation between parties, by placing both parties in an equal position. This partnership contains the meaning of cooperative activities, namely the degree of effort of one party to fulfill the wishes of the other party [4]. According to the researcher himself, a partnership is a collaboration between two parties (people/institutions/groups/ countries) who have one specific goal regardless of status, rank, or position. The purpose of the partnership is that both parties help each other to gain prosperity and realize common goals.

Educational partnership is a collaboration that exists between educational institutions, both formal and non-formal educational institutions, educational institutions with the community, or educational institutions with the private sector. Educational partnerships that exist in an educational institution have a legal basis. There are several legal grounds that can be used in implementing educational partnerships. The legal basis is as follows. The 1945 Constitution Article 31 paragraph 5, which reads "The government advances science and technology by supporting high religious values and national unity for the advancement of civilization and the welfare of mankind." The 1945 Constitution is the legal basis that was first used in carrying out an activity or program [5]. In the 1945 Constitution it is very clear that 
the goal is for national unity and the advancement of national civilization, which means that educational partnerships are one of the activities that can be used to further strengthen the sense of national unity [5]. Next is the National Education System Law No. 20 of 2003, Article 50 paragraph 3 which reads as follows: "The government and/or local governments shall organize at least one education unit at all levels of education to be developed into an international standard education unit [6]. The purpose of international standards is that school partnerships with foreign parties are international partnerships. Next is the National Education System Government Regulation Number 19 of 2005, article 49 paragraph 1 and article 61 paragraph 1. The following is the explanation: "The management of education units at the primary and secondary education levels applies school-based management which is shown by independence, partnership, participation, openness, and accountability." "The government together with the regional government organizes at least one education unit at the basic education level and at least one education unit at the secondary education level to be developed into an international standard education unit [5]." Next up is Law No. 17 of 2007, regarding the 2005-2025 national development plan [7]. This Law describes the long-term development plan of the Indonesian state from various aspects, the following is the explanation: "The National Long-Term Development Year 2005-2025 is a continuation of the previous development to achieve development goals as mandated in the Preamble to the Constitution of the Republic of Indonesia 1945 [5]. For this reason, in the next 20 years, it is very important and urgent for the Indonesian people to rearrange various steps, including in the field of natural resource management, human resources, the environment and its institutions so that the Indonesian people can catch up and have an equal position and strong competitiveness in the international community." In order for Indonesia to catch up with other countries, it takes various efforts from various parties involved in it. One of the efforts that have been made by the world of education in Indonesia is to take an important role in the development of Indonesia towards a better direction, especially in providing quality education.

A good partnership between institutions or institutions in its implementation requires a strong foundation. A strong foundation produces a principle, the principle is mutual trust between institutions or institutions. As stated by Tony Lendrum that a partnership will not exist without a strong principle in it, other than that the concept or idea implemented by each partner should be based on a joint strategy (Tony Lendrum, 2013) in [3], (60-61). Diagrammatically the concepts and principles of partnership can be seen in Figure 1: 


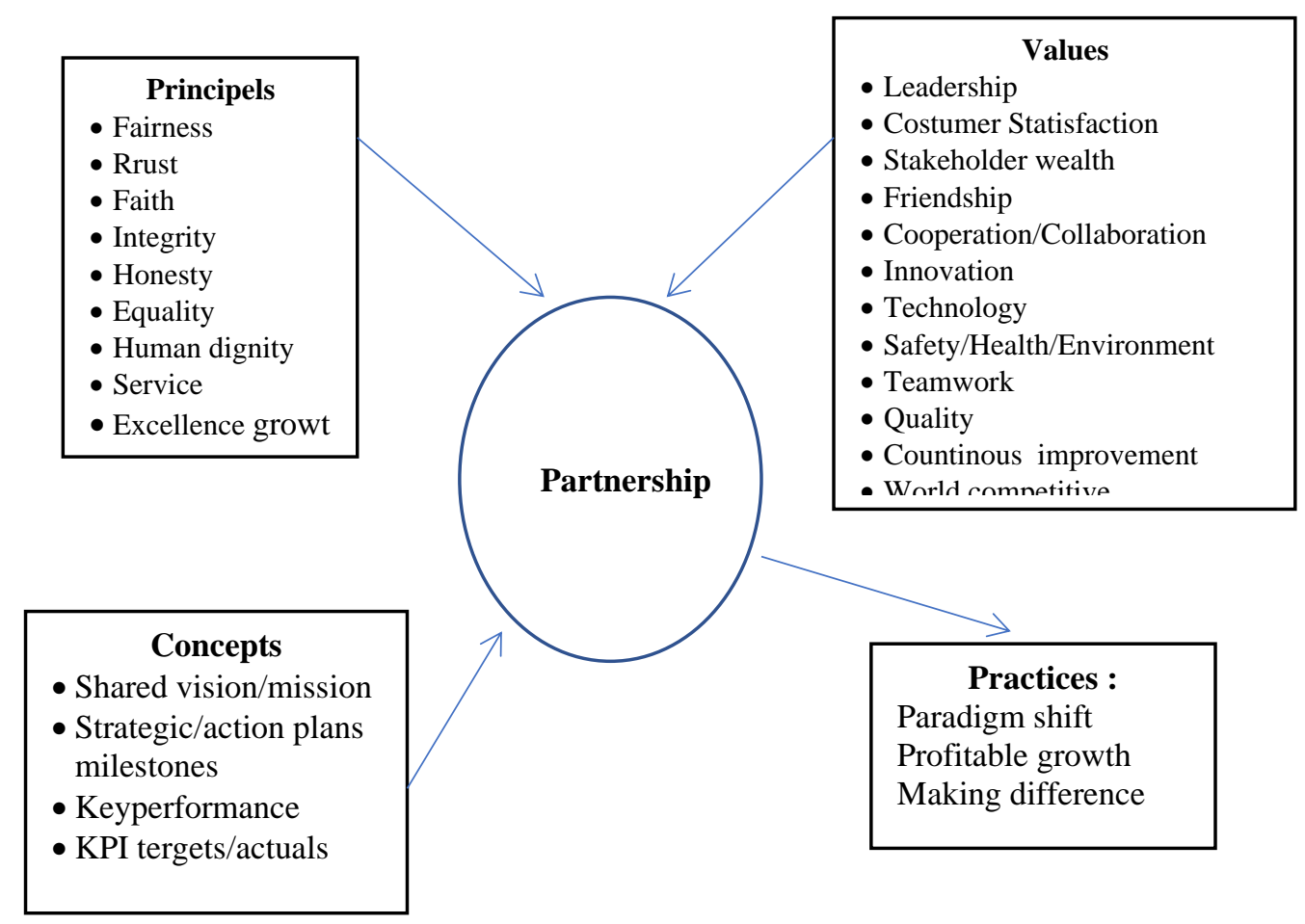

Fig. 1. Concepts and principles of partnership according to tony lendrum.

Fig. 1. shows that the orientation of the collaboration or partnership must lead to a paradigm shift (paradigm shift) in the provision of education. For this reason, in making changes in every activity, it must begin by changing the paradigm in responding to and solving various problems and being oriented towards changing the paradigm that exists in the external environment, [3]. As one example in the explanation of the picture above is Leaderships or leaders must have trust or be able to instill trust in their staff or members so that leaders can share their vision and mission, so that they can develop the institution to be even more advanced. In practice, these values, principles and concepts produce many differences, and in fact the differences that are created become a tool to further develop what are the weaknesses and strengths. Paradigm changes do affect the sustainability of an established collaboration. Fundamentals, values, and concepts are the three things that influence the paradigm shift and the paradigm shift becomes a principle of partnership. In addition, Soekidjo Notoatmojo [2] explains that there are three key principles of partnership, namely equality, openness and mutual benefit.

a. Equity Individuals, organizations, or institutions that have been willing to form partnerships must feel that they "sit the same and stand the same". How big an institution or organization is, if it is willing to form a partnership, it must feel the same. On that basis, in the partnership forum, the principle of democracy must be upheld, one member should not impose his will on another because he feels superior, and there is no domination over the other.

b. Openness (transparency) Openness is what are the strengths or strengths and what are the weaknesses or weaknesses of each member must be known by other members. Likewise, various resources owned by one member must be known by other members. The intention is not to brag about one another, or demean one to another, but rather to understand one another, so that there is no mutual suspicion. This mutual openness will create a sense of complementarity and mutual assistance among members (partners). 
c. Mutual benefit (mutual benefit) Mutual benefit in question is not only profitable in terms of money or material, but more to non-material. Mutual benefit here is seen more from togetherness or synergy in achieving common goals. It's like lifting a weight of $50 \mathrm{~kg}$, lifting four people together is lighter than lifting it alone.

There are several possible partnership models to use. Ambar Teguh Sulistyani [1] describes several partnership models as follows: a) Pseudo partnership, or pseudo partnership. Is an alliance that occurs between two or more parties, but does not actually cooperate with each other in a balanced way. b) Mutualism partnership, or mutualistic partnership is an alliance of two or more parties who are equally aware of the important aspects of doing partnerships, namely to provide mutual benefits and get more benefits, so that they will be able to achieve goals more optimally. c) Conjugation partnership, or partnership through fusion and development. It is the ability of two or more parties to conjugate in order to improve each other's abilities.

Other partnership models developed based on the principles of organizational life in general are as follows: (a) Subordinate union partnership. Is a partnership that occurs between two or more parties, who have status, ability or power that is not balanced with each other, (b) Linear union partnerships. It is the parties who join to carry out cooperation have relative similarities, and (c) Linear collaborative of partnership. Is a partnership that does not distinguish the size or volume, status/legality, or strength of the partners. The most important thing about this partnership relationship is that it is in a straight line, not subordinated to each other.

Furthermore, Soekidjo Notoatmojo [2] explained that there are two partnership models that can be done. a) First Model; The simplest partnership model is in the form of a network or often called also building linkages. This kind of partnership is only in the form of networking. Each partner or institution has its own program starting from planning, implementing and evaluating. The existence of similarities in services or service targets or other characteristics between them, then a network is formed. This type of partnership is also known as a coalition. b) The second model; In this model partnership, it is better and more solid, each member (partner) has greater responsibility for the program or joint activity. The vision, mission, and activities in achieving the goals of the partnership must be planned, implemented and evaluated together.

Partnership Attitudes and Behaviors are also very important in the partnership process. Work attitude (partnership) can be understood as the behavior displayed by each individual worker in the face of every stimulus that occurs in a person's place of work (partnership) [3]. Good partnership attitudes and behavior according to Allan R. Cohen and David L. Branford, [3] are as follows: a) Must be loyal to partners and have the opinion that the overall benefits of partnering work units should take precedence . b) Respect the different perspectives and organizational culture of each partner, even though this may lead to differences. Use the different skills and experiences of partners as a source of learning and creativity. c) Be open-minded about the shortcomings of your partners, because no one is perfect, and those who do business together must give freedom to each of their partners as long as the work unit is not harmed, d) Have the best guess about the motives and basic capabilities of partners You. The point is that if the partner has a lack of ability, it is not because he is stupid or wants to harm, but because the partner does not understand what you mean. Specifically Tony Lendrum, (2013) suggests about nine key words that can be used as indicators of the strategic success of a partnership, namely: 1) Cooperative development; 2) Successful; 3) Long-term; 4) Strategic; 5) Mutual Trust; 6) World class/best practice; 7) Sustainable Competitive advantage; 8) Mutual benefits for all the partners; 9) Separate and positive impact, (Nana Rukmana 2016). Diagrammatically, the strategic elements of the partnership can be seen in 


\begin{tabular}{|c|c|c|}
\hline Workplace & Strategic Partnering & Total Quality \\
\hline $\begin{array}{l}\text { - Enterprise } \\
\text { - Agreement } \\
\text { - Restructuring } \\
\text { - Productivity } \\
\text { - Upskilling/Multi } \\
\text { skilling } \\
\text { - Ownership } \\
\text { - Emowerment } \\
\text { - Attitude/culture } \\
\text { change }\end{array}$ & Partnerships & $\begin{array}{l}\text { - Accreditation } \\
\text { - TQMSPC } \\
\text { - Teamwork } \\
\text { - Attitude/culture } \\
\text { change } \\
\text { - Quality up } \\
\text { - Cost down } \\
\text { - Internal custumers } \\
\text { and simnliers } \\
\end{array}$ \\
\hline $\begin{array}{c}\text { TECHNOL OGY } \\
\text { PROCESS } \\
\text { MADADT TV } \\
\end{array}$ & $\begin{array}{l}\text { Mutualy rewarding, } \\
\text { strong long term } \\
\text { relationships based } \\
\text { on two-way trust, } \\
\text { commitment and }\end{array}$ & $\begin{array}{l}\text { PARTNERING } \\
\text { PROCESS } \\
\text { PARTNERING/ }\end{array}$ \\
\hline $\begin{array}{c}\text { Eternal } \\
\text { Costumers }\end{array}$ & $\begin{array}{l}\text { Coorperation } \\
\text { - World-class }\end{array}$ & Management \\
\hline $\begin{array}{l}\text { - S/ROI large } \\
\text { - Strategic fit } \\
\text { - Shared } \\
\text { information and } \\
\text { vision } \\
\text { - Trust } \\
\text { - World-class }\end{array}$ & - World class products & $\begin{array}{l}\text { - Leader ship } \\
\text { - Vision } \\
\text { - Strategy } \\
\text { - Active } \\
\text { - participantion } \\
\text { - Support }\end{array}$ \\
\hline
\end{tabular}

Fig. 2. Strategic elements of a partnership according to Tony Lendrum. 


\section{Method}

This research is a development research that is developing a synergistic partnership model between study programs in higher education and the school in the context of implementing the independent learning curriculum in schools. The research begins with a needs analysis of the activities needed for mutual benefit between the two partnering institutions to be able to achieve the expected graduate competency goals. Based on the findings of problems in the field and needs analysis, a partnership implementation model along with key activities that can be implemented comprehensively will be designed in an effort to produce graduates with the expected competencies.

The development model used was adapted from Thiagarajan, Semmel, and Semmel (1974) in Trianto [8], namely the development of Four-D Models. The Four-D model consists of 4 stages of development, namely: define, design, develop, and desseminate or be adapted into a 4-P model, namely (1) Defining which includes the initial analysis stage, student analysis, task analysis, concept analysis, and formulation of objectives, (2) Design which includes the stage of designing the implementation model, along with the key activities that will be carried out together. (3) Development includes model validation by experts followed by revision, and simulation, of its use. (4) The dissemination stage is the socialization stage to parties related to the application of the model.

The Define stage is carried out to collect various information related to the partnership model that will be developed. The Define stage includes three steps, namely: (a). Preliminary Analysis, or identify the need to define the underlying problems that arise in the existing partnership system. The initial analysis is intended to obtain an overview of facts, expectations, and alternative solutions to basic problems [9]. This will facilitate the determination and selection of the partnership model and tools to be developed. In this initial analysis, it is used to identify relevant partnership models, as well as identify standard documents and documents that are less relevant, then to determine the documents needed for each model implementation activity to be developed. Based on the factual description of the problems that occur in the field, it is necessary to develop the required partnership model as well as equipment documents that are in accordance with the needs, so it is hoped that the existence of these documents can improve the quality of the synergy of partnering institutions; (b) Curriculum and Partner School Analysis, conducted to examine the characteristics of partner schools in accordance with the curriculum development design used in learning. The curriculum used is the KKNI 2020-based curriculum and is based on the results of development intended for independent learning in schools; (c) Formulating the objectives of the partnership, carried out to determine the behavior of the object of research. The formulation of this goal becomes the basis for compiling and designing the tools needed for the application of the model. Then integrate it into a document that will be developed by the researcher. This is useful to limit the researcher so as not to get out of the original goal.

The Design phase is carried out to design the product to be developed. The initial product must pay attention to feasibility so that it can be implemented in the field. There are several steps that must be taken at this design stage, namely: (a) Identifying the components of the partnership model that will be developed based on curriculum implementation activities that will be carried out in schools, as well as identifying the need for modeling tools, such as MoUs, SOPs, and various forms. guide; (b) Designing the Initial Model based on the model components selected based on the activities to be carried out. This step aims so that the design of the model does not deviate from the needs of curriculum implementation activities in the form of activities in schools; (c) Designing Model Devices based on the implementation needs 
of the selected model based on the activities to be carried out. This step is intended so that the design of various forms of equipment needed does not deviate from the needs of curriculum implementation activities in the form of activities in schools; (d) Selection of the Guide Format (Model Tool) that is in accordance with the basic principles of making the guide. The choice of format in the development of the guide document is intended to design a presentation that meets the criteria of a good document, is attractive, and makes it easy to use.

The Design phase is carried out to design the product to be developed. The initial product must pay attention to feasibility so that it can be implemented in the field. There are several steps that must be taken at this design stage, namely: (a) Identifying the components of the partnership model that will be developed based on curriculum implementation activities that will be carried out in schools, as well as identifying the need for modeling tools, such as MoUs, SOPs, and various forms. guide; (b) Designing the Initial Model based on the model components selected based on the activities to be carried out. This step aims so that the design of the model does not deviate from the needs of curriculum implementation activities in the form of activities in schools; (c) Designing Model Devices based on the implementation needs of the selected model based on the activities to be carried out. This step is intended so that the design of various forms of equipment needed does not deviate from the needs of curriculum implementation activities in the form of activities in schools; (d) Selection of the Guide Format (Model Tool) that is in accordance with the basic principles of making the guide. The choice of format in the development of the guide document is intended to design a presentation that meets the criteria of a good document, is attractive, and makes it easy to use.

Development Stage (Develop) which is the stage to produce product development. The purpose of this stage is to produce the final form of the developed model and device after going through a revision process based on input from the validator and data from the development trial results. At the development stage, there are 2 steps, namely: (a) discussing the model draft and model device documents that have been prepared through the FGD to obtain input and revisions; (b) conducting limited trials in partner schools involving components involved in the lecture process at schools to determine the implementation of the developed model; and (c) Conduct expert appraisals and users to determine the level of feasibility.

Data collection techniques in this study used instruments in the form of questionnaire FGD guidelines, interview guidelines and documentation. In addition, to collect the required data regarding the feasibility of the model, an instrument related to the feasibility level of the model was developed

\section{Result and Discussion}

The initial activity of the research was to analyze the performance needed by the two partnering institutions, namely to clarify performance issues and activities needed in partnership activities between partnering educational institutions. This analysis is used as part of the required model design requirements. Based on the needs and patterns of involvement of the two partnering institutions, the aspects that are needed and must be known in the partnership activities include (1) formulation of indicators for the two partnering institutions, (2) interaction patterns needed as a requirement in the partnership process, and ( 3 ) the need for student activities that implement the independent curriculum in partner schools. Based on the identification results from these aspects, the activities to be carried out will be identified, 
and these activities require guidance in their implementation, as well as a joint commitment document in the form of an MoA between partnering institutions. Model identifikasi aktifitas yang dipelukan dalam proses kemitraan ini, secara rinci digambarkan pada Gambar 3. Gambar ini menjadi acuan dalam mengidentifikasi setiap aspek beserta aktifitas yang ditimbulkannya.

Based on the formulation of the activities required in the partnership activities, the next step is to design a partnership model between SMK and PTE Study Program. The partnership model is designed with reference to efforts to achieve synergistic achievements for actors in the partnership process. To achieve these conditions, the partnership model is designed by identifying the interactions between partnership actors in producing achievements for each actor involved in partnership activities (Figure 4).

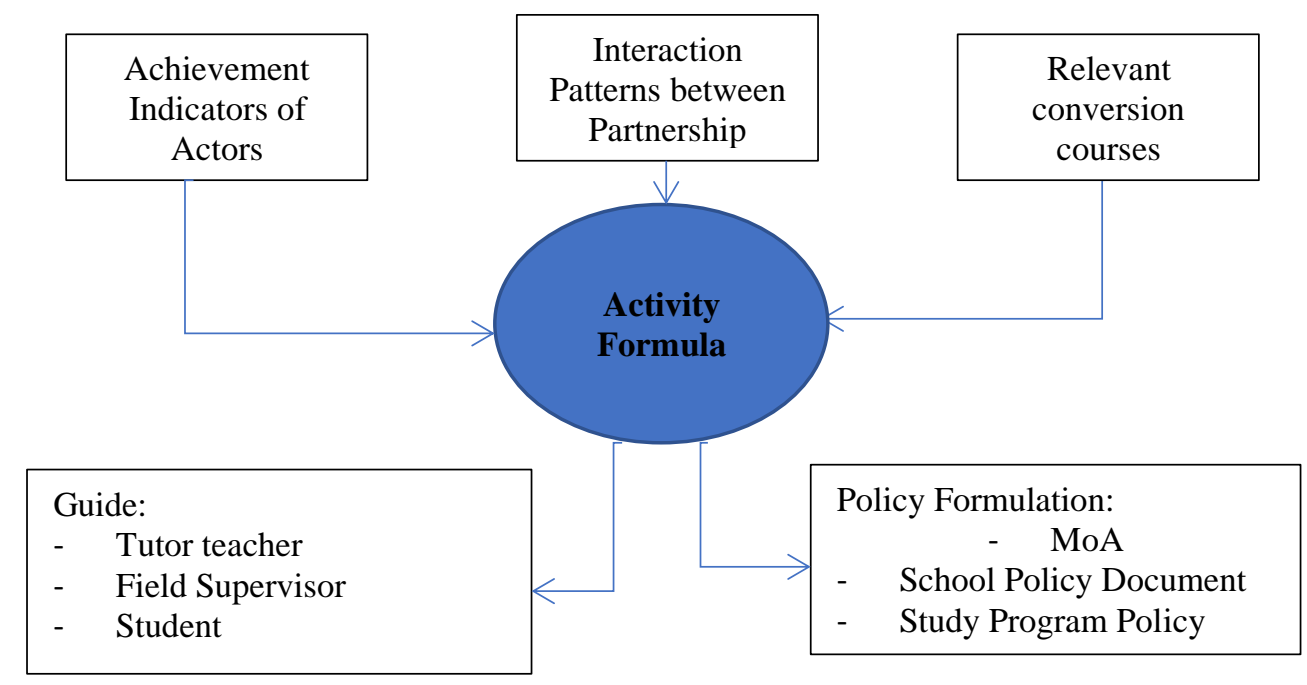

Fig. 3. Cooperation activity formulation model. 


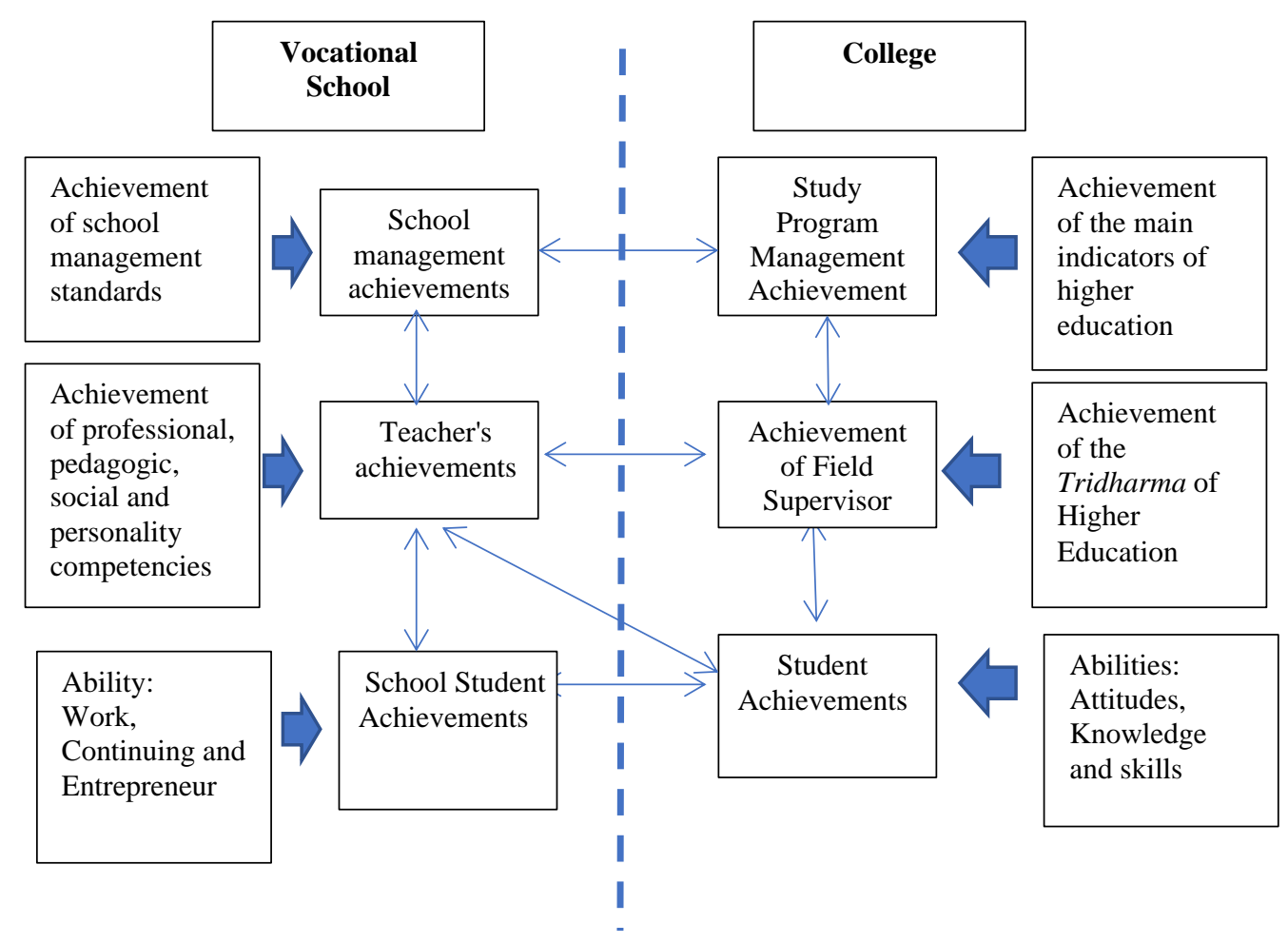

fig. 4. Model of interaction pattern in achieving performance of cooperation actors.

Based on the results of the identification of the activities and recommendations that have been collected through discussion activities, it is obtained that activities that are part of the activities of the Study Program Manager (Head of Study Program), School Management (Principal/Vice Principal, Field Supervisor Lecturer, Civil Service Teacher, student activities and school student activities The formulation of activities obtained indicates the need for several recommendations needed to support activities that are mandatory for partnership actors.

The formulation of the activities of the Study Program Manager (Head of Study Program) includes: (1) Managing and administering student applications, (2) Conducting communication and correspondence between institutions, (3) Carrying out socialization to prospective field supervisors, (4) Formulating and determining activities students based on the conversion components proposed by students, (5) Arrange assignments for field supervisors for students, (6) Recommend partnership activities (in the form of research and community service) with teachers in schools, and (6) Plan activities to strengthen teacher competence in the form of mentoring from the LPTK lecturer. The implementation of this activity formulation requires policy recommendations such as; (1) There needs to be a service standard for students who will carry out activities at school, (2) There needs to be a mechanism for determining field supervisors, (3) There needs to be a formulation of joint partnership activities between lecturers and teachers in order to fulfill the achievement of competence and the tridharma of higher education, and (4) Need facilitation for lecturers and teachers who will 
carry out competency strengthening, and partnership activities in the form of research and community service.

The formulation of activities that are part of the activities of School Management (Principal/Vice Principal) consists of: (1) Conducting communication and correspondence between institutions, (2) Carrying out socialization to prospective civil servant teachers in accordance with agreed criteria, (3) Prepare assignments for tutors for students based on their needs, (4) Recommend partnership activities (in the form of research and community service) that are possible to be carried out by lecturers in schools, and (6) Recommend activities for strengthening teacher competence in the form of mentoring from LPTK lecturers. This activity requires the support of recommendations such as: (1) There needs to be a mechanism for determining civil servant teachers, (2) There needs to be a formulation of joint partnership activities between lecturers and teachers in order to fulfill the achievement of competence and the tridharma of higher education, and (3) Need facilitation for teachers and lecturers which will carry out competency strengthening, and partnership activities in the form of research and community service.

The formulation of activities that are part of the activities of the Field Supervisor consists of: (1) Participating in socialization as a prospective field supervisor, (2) Identifying student activities to be mentored based on the conversion components proposed by students, (3) Preparing plans, bills, and guidance materials for students, (4) Coordinate with civil servant teachers assigned by the school, (5) Implement guidance, mentoring, and monitoring of student activities carried out in schools, (6) Prepare partnership activities (in the form of research and community service) with teachers in schools, and (6) Carry out competency strengthening activities through mentoring to teachers. Policy recommendations needed in the implementation of field supervisor activities consist of: (1) There needs to be service standards for students related to plans, bills, and guidance materials for students; and (2) there needs to be a formulation of joint partnership activities between lecturers and teachers in order to fulfill the achievement of competence and the tridharma of higher education.

The formulation of activities that are part of the activities of the Civil Service Teacher consists of: (1) Participating in socialization as a prospective civil servant teacher, (2) Studying student activities to be guided based on the conversion components proposed by students, (3) Preparing plans, bills, and guidance materials for students, (4) Coordinate with field supervisors assigned to Study Program, (5) Implement guidance, mentoring, and monitoring of student activities carrying out activities at school, (6) Prepare partnership activities (in the form of research and community service) with teachers in schools, and (7) Carry out competency strengthening activities through mentoring from lecturers. Policies needed in the implementation of activities include: (1) There needs to be service standards for students related to plans, bills, and guidance materials for students, and (2) There needs to be a formulation of joint partnership activities between lecturers and teachers in order to fulfill competency achievement. and the tridharma of higher education.

The formulation of student activities carried out in partnership activities include: (1) Proposing an activity plan for implementing the Merdeka curriculum in schools, (2) Arranging activities based on the components of the courses to be converted, (3) Coordinating with field supervisors assigned by Study Programs, related to the mechanism of guidance, billing, and monitoring activities, (4) Coordinate with tutors assigned by the school, related to the mechanism of guidance, billing, and monitoring activities, (5) Prepare materials and activity tools in accordance with the direction of the supervising lecturers and teachers civil servant, and (6) Carry out activities at school with the assistance of the civil servant teacher. Meanwhile, school student activities include: (1) Studying as usual with subject teachers, (2) 
Studying and doing activities with students with teacher guidance, and (3) Providing input when reflecting on student activities. For the success of student and student activities, policies related to: (1) There needs to be service standards for students related to plans, bills, and guidance materials for students, and (2) It is necessary to establish a mechanism for monitoring and monitoring student activities by the civil servant teacher and field supervisor.

The results of the verification of the activities of the partnership actors starting from management activities to the activities of students and school students are shown in Table 1.

Table 1. Data on the verification of the relevance level of partnership actor activities

\begin{tabular}{clcccc}
\hline No & Partnership Actors Activities & Stage I & Decision & Stage II & Decision \\
\hline 1 & $\begin{array}{l}\text { Study Program Management } \\
\text { (Head of Study Program) }\end{array}$ & 4.23 & Very Relevant & 4,62 & Very Relevant \\
2 & $\begin{array}{l}\text { School Management } \\
\text { (Principal/Vice Principal, }\end{array}$ & 3.51 & Relevant & 4,22 & Very Relevant \\
3 & Field Supervisor & 3.46 & $\begin{array}{c}\text { Relevant } \\
\text { Relevant }\end{array}$ & 4,47 & Very Relevant \\
4 & Tutor teacher & 3.24 & $\begin{array}{c}\text { Very Relevant } \\
\text { Relevant }\end{array}$ & 4,22 & Very Relevant \\
5 & Student activities & 4.11 & 4,36 & Very Relevant \\
6 & School student activities & 3.52 & Relevant \\
\hline
\end{tabular}

The results of the assessment of the level of relevance of the activities of the partnership actors show that the formulation of activities for each of the actors of the partnership activities is very in line with the purpose of the partnership activities, and even the formulations that have been prepared are very detailed based on the needs of each partnership actor. The suitability of the level of relevance of the activities of the partnership actors will provide confidence in the usefulness of the partnership program that is carried out. The usefulness of partnership activities based on the assessment of the sources shows that there is a synergistic impact generated, and supports the main functions and tasks of each partnership actor. The results of the assessment of the impact of the activities of the partnership actors in achieving the partnership targets are shown in Table 2.

Table 2. Data on impact assessment results of partnership actors.

\begin{tabular}{|c|c|c|c|}
\hline No & Partner actors & $\begin{array}{c}\text { Average } \\
\text { Activity } \\
\text { Impact } \\
\text { Assessment }\end{array}$ & Note \\
\hline 1 & $\begin{array}{l}\text { Study Program Management } \\
\text { (Head of Study Program), }\end{array}$ & 4.47 & $\begin{array}{l}\text { Impact on Improving the achievement of the } \\
\text { main indicators of higher education. }\end{array}$ \\
\hline 2 & $\begin{array}{l}\text { School Management } \\
\text { (Principal/Vice Principal, }\end{array}$ & 4.38 & $\begin{array}{l}\text { Impact on achievement of SMK management } \\
\text { indicators }\end{array}$ \\
\hline 3 & Field Supervisor & 4.26 & $\begin{array}{l}\text { Impact on increasing the activities of higher } \\
\text { education tridharma. }\end{array}$ \\
\hline 4 & Tutor teacher & $4, .52$ & Impact on teacher competency improvement \\
\hline 5 & Student activities & 4.25 & $\begin{array}{l}\text { Impact on increasing student capacity as } \\
\text { teacher candidates }\end{array}$ \\
\hline 6 & School student activities & 4.33 & $\begin{array}{l}\text { Impact on increasing student learning } \\
\text { capacity. }\end{array}$ \\
\hline
\end{tabular}


The partnership model developed as a result is supported by products in the form of program implementation guidelines that are the subject of the partnership, the formulation of the activities of the actors, as well as policy documents developed in study programs and schools. The resulting product is a final product that functions as an integral part of the partnership model that will be implemented. The final product of the development of the resulting partnership model is also carried out with a feasibility test by experts and resource persons from universities and schools. The results of the feasibility test (Table 3) show that all the final products produced are very feasible to be used in partnership activities.

Table 3. Product feasibility test results.

\begin{tabular}{clcl}
\hline No & \multicolumn{1}{c}{ Validated Aspect } & $\begin{array}{c}\text { Average Eligibility } \\
\text { Assessment Results }\end{array}$ & \multicolumn{1}{c}{ Decision } \\
\hline 1 & Partnership Model & 4.47 & Very Worthy \\
2 & Activity Guide in partnership & 4.56 & Very Worthy \\
3 & Activity Formulation and & 4.52 & Very Worthy \\
& Recommendations & & \\
4 & Draft MoA & 4.65 & Very Worthy \\
5 & Study Program Policy Document & 4.32 & Very Worthy \\
6 & School Policy Document & 4,43 & Sangat Layak \\
\hline
\end{tabular}

\section{Conclusion}

The results of the research on the development of this partnership model found that: (1) the formulation of activities for implementing the independent learning curriculum in partner schools that were packaged in the components of the partnership model was very relevant to be used in the process of partnership activities; (2) partnership activities have a positive impact on partnership actors based on their respective roles, where study program management will have an impact on achieving the main indicators of higher education, school management will have an impact on achieving school management indicators, the activities of field supervisors will have an impact on increasing three-level activities. dharma of higher education, the activities of civil servant teachers will have an impact on increasing teacher competence; and student activities will have an impact on increasing student capacity as prospective teachers; (3) The partnership model and supporting device products were found to be very feasible to be applied in supporting the implementation of learning in schools. The results of this study are expected to be followed up, and expanded based on the needs of the institution, so that there is a synergy between educational institutions and education staff with schools as one of the users of graduates. The implementation of the independent learning curriculum in schools is also expected to be part of the implementation of the new paradigm curriculum in schools. 


\section{References}

[1] Sulistyani AT. Kemitraan dan model-model pemberdayaan. Yogyakarta: Gava Media; 2014.

[2] Notoatmojo S. Pendidikan dan Perilaku Kesehatan. Jakarta: Rineka Cipta; 2013.

[3] Rukmana N. Strategic Partnering For Educational Management (Model Manajemen Berbasis Kemitraan). Bandung: Alfbeta.; 2016.

[4] Melyanti IM. Pola Kemitraan, Civil Society, dan Swasta dalam Program Bank Sampah di Pasar Baru Kota Probolinggo. Available from http://journal.unair.ac.id/download-fullpaperskmpe0736a7a4efull.pdf; 2014. [Accessed 21 ${ }^{\text {th }}$ April 2016].

[5] Undang-undang Dasar Negara Republik Indonesia Tahun 1945. Available from www.itjen.depkes.go.id/public/upload/unit/pusat/files/uud1945.pdf. [Accessed at $23^{\text {th }}$ February 2016]

[6] Undang-undang Sisdiknas No 20 tahun 2003. Available from http://kemenag.go.id/file/dokumen/UU172003.pdf. Direktorat Jendral Pendidikan Dasar dan Menengah, Direktorat Sekolah Lanjutan Tingkat Pertama. Jakarta: Depdiknas; 2001 [Accessed 23 February 2016] .

[7] Undang-undang No 17 Tahun 2007. Tentang Rencana Pembangunan Nasional. Available from http://www.dpr.go.id/dokjdih/document/uu/UU_2007_17.pdf. [Accessed 23 ${ }^{\text {th }}$ Februari 2016 ].

[8] Trianto. Mendesain Model Pembelajaran Inovatif-Progresif. Jakarta: Kencana; 2019.

[9] Sugiyono. Metode Penelitian Kuantitatif Kualitatif dan R\& D. Bandung: Alfabeta; 2010. 